\title{
The Russian Orthodox Episcopate, 1721-1917: A Prosopography
}

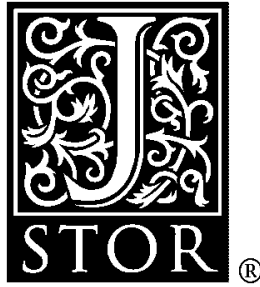

Jan Plamper

Journal of Social History, Vol. 34, No. 1. (Autumn, 2000), pp. 5-34.

Stable URL:

http://links.jstor.org/sici?sici=0022-4529\%28200023\%2934\%3A1\%3C5\%3ATROE1A\%3E2.0.CO\%3B2-9

Journal of Social History is currently published by Peter N. Stearns.

Your use of the JSTOR archive indicates your acceptance of JSTOR's Terms and Conditions of Use, available at

http://www.jstor.org/about/terms.html. JSTOR's Terms and Conditions of Use provides, in part, that unless you have obtained prior permission, you may not download an entire issue of a journal or multiple copies of articles, and you may use content in the JSTOR archive only for your personal, non-commercial use.

Please contact the publisher regarding any further use of this work. Publisher contact information may be obtained at http://www.jstor.org/journals/pns.html.

Each copy of any part of a JSTOR transmission must contain the same copyright notice that appears on the screen or printed page of such transmission.

The JSTOR Archive is a trusted digital repository providing for long-term preservation and access to leading academic journals and scholarly literature from around the world. The Archive is supported by libraries, scholarly societies, publishers, and foundations. It is an initiative of JSTOR, a not-for-profit organization with a mission to help the scholarly community take advantage of advances in technology. For more information regarding JSTOR, please contact support@ jstor.org. 


\section{THE RUSSIAN ORTHODOX EPISCOPATE, 1721-1917: A PROSOPOGRAPHY}

\section{By Jan Plamper}

\author{
University of California, Berkeley
}

The Russian episcopate's almost exclusive reliance upon a pool of parish clergy sons from the mid-eighteenth century until 1917 knew no parallel in Western or Central Europe, where bishops were from the nobility and increasingly from the middle classes. ${ }^{1}$ Only British nineteenth-century Anglican bishops, 32.4 percent of whose fathers were clergymen, remotely resembled the social origins of the Russian episcopate. ${ }^{2}$ In Russia, between 1800 and 1900 a total of 319 or 92.5 percent out of 345 prelates whose social background is known were born into the clerical estate (soslovie), Russia's most hereditary, caste-like social group. ${ }^{3}$ If kinship ties between the episcopate and the parish clergy were this strong, why would a parish priest in the 1850 s pen a manifesto, in which he blamed the bishops for all but a few of the clergy's severe problems, stating that "the relationship between priest and bishop is exactly like that between Negro and plantation owner?"' In this prosopography of the 731 Russian Orthodox bishops consecrated between the Petrine Church Reform of 1721 and the October Revolution of 1917 I hope to advance, among other things, a fresh answer to this question of the rift between clergy and episcopate. ${ }^{5}$ I explore the regional and social origins of the episcopate and inquire when the shift to a closed social group occurred as well as what dynamics governed the preponderance of bishops from certain regions over those from others. Second, I examine the episcopate's educational patterns, the level of education required for becoming a black (monastic) clergy candidate for a bishop's post, and the ecclesiastical educational institutions which most frequently produced the graduates who later went on to become prelates. Third, I investigate the careers of these men before they were ordained as bishops, and finally, I analyze episcopal career patterns, focusing on the wider implications of the frequency and geographical variation of transfers from one diocese to another. As a collective biography with Western and Central Europe as points of comparison, this article ultimately hopes to better assess the locus of the Orthodox episcopate in the Imperial Russian social fabric. It should be of interest to students of Russian élites (nobility, bureaucracy, professions) and European ecclesiastical élites, but also more generally to students of Russian religious and social history. ${ }^{6}$

******

Compared with the episcopate of Imperial Russia, Orthodox prelates in prePetrine Muscovy had radically different origins and functions. Like their Imperial successors they were recruited mainly from the black clergy; their monasticism, however, emphasized asceticism, reclusion, and liturgy over the broad humanistic theological education of the "learned monks" (uchenoe monashestvo), favored by Peter the Great. Pre-Petrine Orthodoxy negatively identified learned monks 
with Roman Catholicism. The particular monastery to which a Muscovite monk belonged had a socializing impact of paramount importance: it inculcated its special theological views, its liturgical and ascetic practices in its monks, who, if appointed bishops, spread their monastery's "school" to their diocese. ${ }^{7}$ The most fundamental difference between ascetic and learned monks, however, was that the latter merely received a monk's tonsure, but almost never led a monastic life; they served pedagogical functions, primarily in ecclesiastical seminaries and academies.

The shift to educated monks occurred during Peter the Great's reign, when the Church began to require above all skilled administrators to accomplish the new tasks it had been assigned during the Petrine era. Chief among these was the effective implementation of centrally issued Church policy in the dioceses, particularly the construction of educational institutions for the parish clergy, who, in turn, were to carry out Peter's order to educate society. From the second half of the eighteenth century, it increasingly became the Church's own vested interest to consecrate skilled administrators, for these had to defend its interests vis-à-vis an increasingly efficient state bureaucracy, and, by overseeing the parish clergy, guarantee Orthodoxy's continued grip on the lay folk, among whom sectarian and schismatic religious movements were gaining currency.

\section{Regional Origins}

Peter the Great found the candidates who would meet his requirements among non-Great Russian, particularly Ukrainian, but also foreign monks. The shift away from Great Russian bishops generated conflicts with the incumbent episcopate, the parish clergy, and the laity. This relationship improved only when the first graduates of Great Russian seminaries and academies, founded in the immediate post-Petrine era, embarked upon their episcopal careers during Catherine the Great's reign. Another factor contributing to the increasing regional diversity of the eighteenth-century episcopate's origins was the expansion of the Russian Empire and the rise in non-Great Russians among potential future bishops. At the same time, the number of dioceses increased and mobility became an overriding structural feature of a bishops' career path. During ecclesiastical education students began to move far from their father's parish and between different seminaries and academies, and later as administrators and pedagogues they moved from one institution of ecclesiastical education to another, as bishops from one diocese to another. Mobility led to the formation of a unified episcopal esprit de corps, so that by the nineteenth century the regional origins of a bishop played virtually no role in shaping his identity.

In terms of the importance of a bishop's regional background, the two centuries under concern can be broken down into three phases: 1. 1721-1760s 2 . 1760 s-1800 3. 1800-1917. ${ }^{8}$ During the first phase the non-Great Russian bishops appointed by Peter had mostly attended the ecclesiastical academy of Kiev, renowned for the Western-style humanistic and theological education it had to offer. Some had indeed studied in the West. ${ }^{9}$ The appointment of non-Great Russian bishops to Great Russian dioceses constituted a conscious break with Church practice, especially considering that Russian was a foreign language for the Ukrainian bishops and not spoken at all by some foreign prelates. Most signif- 
icant, it was a deliberate attempt by Peter to gradually silence the voices of those Great Russian hierarchs who so vehemently opposed the extension of his Westernizing reform measures to the Church. And although the non-Great Russian prelates proved to be by no means monolithically reform-minded, their Great Russian colleagues certainly perceived and resented them as a politically acquiescent group. ${ }^{10}$ In fact, if one of Peter the Great's negative images (among Old Believers) was that of the anti-Christ, the orthodoxy of the hierarchy promoted by Peter was questioned no less by the established Great Russian bishops. ${ }^{11}$

To illustrate Peter the Great's penchant for non-Great Russian bishops, 61.4 percent of the 44 prelates consecrated between the death of the last patriarch in 1700 and Peter's own death in 1725 were non-Great Russian. ${ }^{12}$ The preponderance of these hierarchs in the first quarter of the eighteenth century was remarkable not only in terms of numbers, but also in a qualitative sense, for they were appointed to many of the most important dioceses. ${ }^{13}$ Moreover, they usually brought their own Ukrainian staffs with them, thereby making their presence felt even more acutely. The selection of the episcopate from outside Great Russia continued long after Peter's death. It only came to a halt in the 1760 s when the élite graduates of the new ecclesiastical educational institutions, set up in central Russia from the 1720 s on, reached the point in their careers at which they became eligible for episcopal positions.

The second phase (1760s-1800) was characterized by an increase in Great Russian bishops. Thirteen bishops of Great Russian origin and merely two Ukrainian hierarchs were consecrated in the 1760 s. This sharp increase in Great Russian prelates appears all the more dramatic if one considers that only seven had been ordained in the preceding four decades. Again, the principal reason for this radical change was the availability of a new generation of graduates from the new Central Russian ecclesiastical academies. Another factor was the suspicion Ukrainian and foreign bishops aroused among both laity and clergy. Empress Elizabeth sought to solve this problem by issuing a decree (ukaz) in 1754, ten

Figure 1

Geographical Origins, 1721-1760

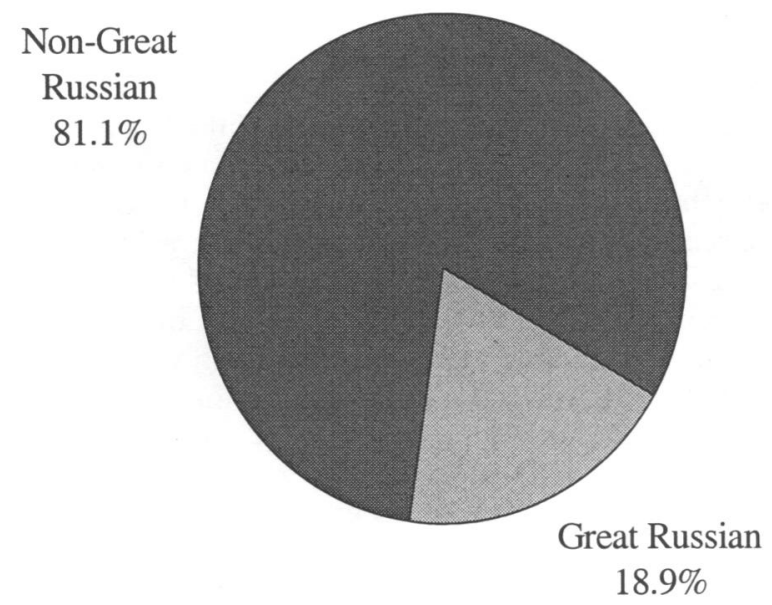


Figure 2

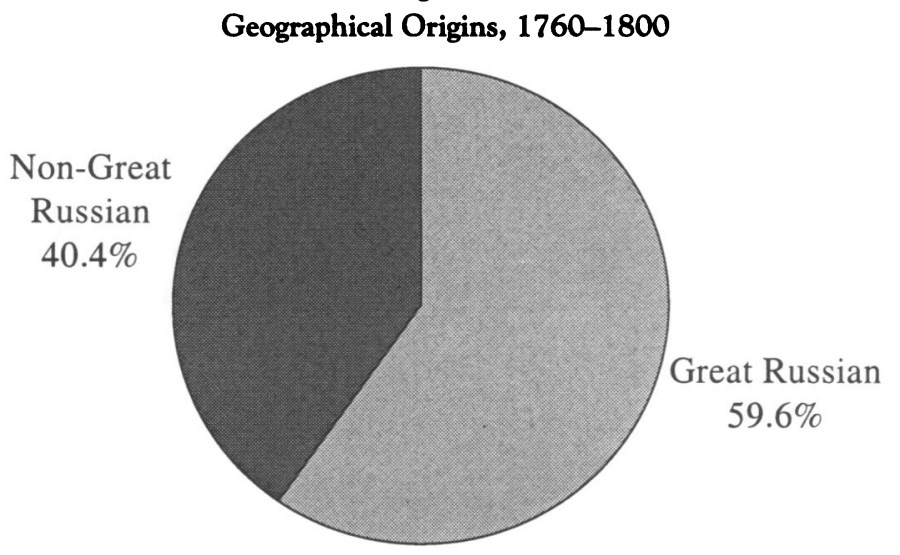

years after the last Great Russian had been consecrated as a bishop, in which she ordered that the Holy Synod again consider Great Russians for vacant dioceses. Palpable change, however, came only during Catherine the Great's reign (176296). In diametrical opposition to Peter the Great's practice, Catherine showed a distrust for Ukrainian bishops, especially after her secularization of Church lands in 1764 had met with fierce resistance by the Mitropolitan of Rostov, Arsenii Matseevich, a Ukrainian by origin. ${ }^{14}$

By the 1820s a unified collective identity of the episcopate had formed and geographical origin had ceased to be a differentiating factor. From roughly 1800 until 1917, the third phase, the hierarchy, though more diverse in its regional heritage than ever, effectively defended its interests against the state and the parish clergy during times of political upheaval, such as the Great Reforms and the 1905 Revolution.

\section{Social Origins}

The pre-Petrine Orthodox hierarchy was a socially mixed group of men, derived from the nobility, clerical estate, bureaucracy, meshchanstvo (the townspeople, composed of merchants, petty traders, and unskilled labor), and the army. ${ }^{15}$ The hierarchy appointed between the death of the last Patriarch Adrian in 1700 and Peter the Great's death in 1725 was primarily of noble origin (65.4 percent), but also comprised merchants' sons (15.4 percent), clergy's sons (11.5 percent), and two Cossacks' sons ( 7.7 percent). ${ }^{16}$ Prelates from the nobility predominated because of the large influx of Ukrainian, Polish, and White Russian graduates of Kiev Academy, many of whom belonged to the Polish shliakhetstvo.

Data on the social origins of the hierarchy appointed between Peter's death and Catherine the Great's enthronement in 1762 are meager. ${ }^{17}$ The following picture emerges: to list the main groups, 46.7 percent were of clerical stock, 26.7 percent had noble fathers, 10.0 percent were born to military fathers, and 10.0 percent came from merchant families. ${ }^{18}$ Here the most remarkable feature is the large aristocratic segment, which was on the decline commencing with the 
1750s during Elizabeth's reign. From the 1760s on, the nobility never furnished more than 11.0 percent of the bishops ordained during any given reign until the end of autocracy in 1917. The clerical estate, by contrast, was the social group from which the great majority of prelates was drawn-starting with the 1760 s, in no decade were fewer than seventy percent of clerical origin and from the 1820 s until the 1840 s all bishops were of clerical stock.

The watershed in the hierarchy's social composition during the 1750s was due, above all, to the increasingly clerical heritage of the new central Russian seminary and academy student bodies, who received preference over their nonGreat Russian counterparts in the episcopal selection process from the 1750 s on. Second, Peter the Great greatly restricted access to monastic tonsure, thereby virtually barring the nobility from entering the black clergy. In Peter's scheme, aristocrats played too important a role as servitors to the state-in the army and bureaucracy-to allow them to join monasteries, which he considered breeding grounds of idleness (and to which he assigned social welfare tasks, by putting them in charge of orphans, elders, ill people, and soldiers retired from service).

From the mid-eighteenth century until 1917 bishops were almost exclusively clergy's sons. Under Catherine 73.3 percent had clerical origins, under Paul 77.8 percent, during Alexander I's reign 91.7 percent, followed by 95.9 percent, 93.4 percent, 96.3 percent, and 79.4 percent under Nicholas I, Alexander II, Alexander III, and Nicholas II respectively. ${ }^{19}$ In nineteenth-century Russia, a maximum of 7.4 percent in the era of Alexander II was of aristocratic stock. During the entire period, from 1721 until 1917, a total of 420 (86.4 percent) of the 486 prelates (total consecrated: 731 ) whose social origin is known, were born into the clerical estate.

The parish clergy, however, was socially and functionally differentiated, too. It was made up of ordained clergy, comprising archpriests, priests, and deacons, as well as the lower strata sacristans. ${ }^{20}$ Even though sacristans constituted half of the clergy, their sons were represented with a mere 15.8 percent in the Imperial

Figure 3

Percentage of Bishops from Clerical Estate

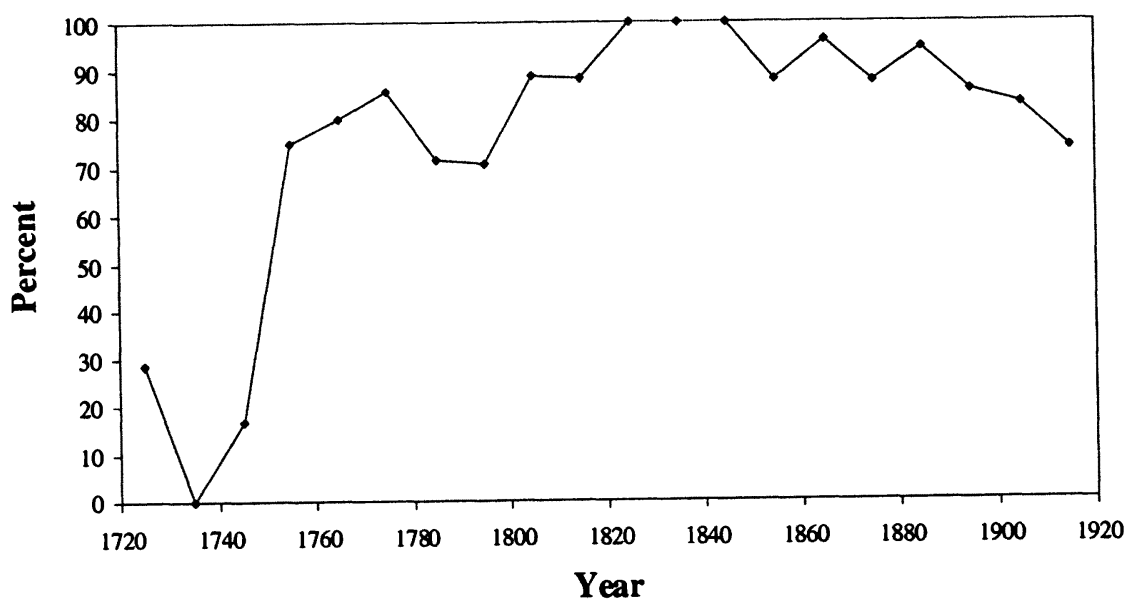


Russian episcopate. In a given year, in 1824, for example, there were 34,095 (31 percent) priests and archpriests, 15,081 deacons (14 percent), and 59,740 sacristans ( 55 percent) in Russia. In that decade, the $1820 \mathrm{~s}, 63.6$ percent of the ordained prelates had priests and archpriests as fathers, 4.5 percent deacons, and only 27.3 percents sacristans. Sacristans' sons were underrepresented because their fathers could ill afford to send them to a seminary and subsequently to an academy with the pittance they earned.

Thus Russia's episcopate was a peculiarly composed social group from the 1750s on: its well-nigh exclusive dependence upon a pool of parish clergy's sons knew no parallel in other European countries, where bishops were more noble in social origin. ${ }^{21}$ Due to a set of legal, educational, economic, and cultural barriers, the clergy itself was the most rigidly hereditary of all estates, permitting only a miniscule number to leave the clerical estate and a trifling few from other estates to enter it. ${ }^{22}$ Bishops owed allegiance first and foremost to the Church, not to their fathers' profession and its corresponding social status, or to their diocese with its priests and parishioners. They did not, however, coalesce into a cohesive political interest group until the Great Reforms of the 1860s, when they vigorously defended their own vested interests against both the state and the parish clergy. Hence Russia's episcopate is best characterized as a group, whose education and pre-episcopal positions more than any other factor shaped their collective political behavior.

\section{Education}

Ecclesiastical education was the single most important stratifying phase in a clerical life. As the first hurdle in any ecclesiastical education, the seminary functioned as the main filtering site for the clerical estate. In the walls of the seminary a Darwinian selection process of sorts took place with only the-physically and psychologically, not necessarily intellectually-fittest graduating. Like all seminarians, the future bishops as a rule attended the seminaries closest to their fathers' parishes. During the eighteenth century, the traditional central Russian seminaries stand out in episcopal biographies. ${ }^{23}$ In the nineteenth century two new trends became noticeable: first, prelates had no longer overwhelmingly attended central Russian seminaries but were increasingly graduates of seminaries spread across the Empire and, second, seminarians enrolled not in the academy closest to their seminary but in more distant academies.

Traditionally the rift that opened between the episcopate and the parish clergy has been explained by the Synodal practice of diocesan transfers. But in fact the two groups parted ways earlier in life. The crux of the rift between prelates and parish priests, which became so acute over the nineteenth century, lies precisely in the pattern of geographic mobility that was already part of a bishop's education. During his formative years, a bishop-to-be emerged victorious over weaker clerical sons in a battle for survival in the seminary, from where he moved to a far-away academy. In the academy, he joined other "survivor" seminarians and a collective identity that pitted the future bishops against their own estate, in the incarnations of both their fathers and the other priests' sons who had proven less fit in the seminary. ${ }^{24}$

For the clerical estate as a whole, the general pattern of seminary education in 
Imperial Russia was one of intermittent, small growth until 1755, a period of rapid expansion until 1764 , followed by a decade of dropping enrollments, and overall increase, despite fluctuation, in the nineteenth century, as the seminary degree had became a virtual sine qua non for a clerical parish position and as a surfeit of clergy's sons vied for the vacant positions. The education of bishops fits the general pattern of the entire clerical estate's schooling, though not without some important modifications. The information on episcopal seminary education is ambiguous for the period of 1721 until 1810, with data on merely forty-three (23.5 percent) of the hierarchs consecrated. It is difficult to determine whether this small percentage should be attributed to veritably low enrollments or to gaps in the data. Nevertheless, since a seminary education was the prerequisite for entrance into one of the four academies, seminary and academy data can be correlated, the latter being more complete (it is known of 43.7 percent of the 183 prelates ordained between 1721 and 1810 that they attended an academy). Almost half (48.8 percent) of the hierarchs under concern attended a seminary in central Russia, reflecting the spreading of seminaries from center to periphery and also testifying to the élite status of the oldest seminaries in the center. Another 34.9 percent were from Northwestern seminaries, compared with the combined mere 16.3 percent from all other regions. The correlation between seminary graduates from central Russia and graduates of Moscow Academy is very high indeed (81.8\%); overall, however, Kiev Academy trained 70.0 percent of the bishops with academy degrees during our period, Moscow Academy only 27.5 percent, and St. Petersburg a trifling 2.5 percent. Kiev's preponderance can be explained by the overwhelming presence of Ukrainian prelates until the mid1750 s, for most of whom we do not know their education below the academy level. Moreover, in eighteenth-century Russia Kiev was the undisputed center of theological learning; its learned monk teachers were exported to Moscow and St. Petersburg Academies and its curriculum served as the model.

The second period (1811-70) shows not only a greatly increased number of bishops who attended a seminary ( 74.0 percent), but also a much wider range of seminaries from all over Russia. Such seminaries as Orel and Tambov in the Blacksoil region now produced almost as many graduates (nine and eight respectively) whose careers culminated in episcopal appointments as the traditional central Russian seminaries of Moscow and Iaroslavl' (eleven and seven respectively). Still, the central region's seminaries continued to supply 44.4 percent of the bishops, now followed by graduates from Blacksoil institutions (this rise can be attributed to successful recruitment efforts for ecclesiastical schools in the heartland of traditional peasant piety). Significantly, the Northwest lost its distinction as the second-most important educational region and now furnished only 14.2 percent of the seminary graduates. 11.1 percent finished at Ukrainian seminaries. Between 1811 and 1870 the distribution of students at the Academies of Kiev, Moscow, and St. Petersburg was far more balanced: 35.9 percent enrolled at St. Petersburg Academy, 31.7 percent in Moscow, and 30.3 percent in Kiev. Kazan' Academy, which had opened in 1844, had lower admission standards and therefore graduated only three students ( 2.1 percent) who later became prelates. Moscow Academy had the highest percentage of seminarians from its surrounding areas (73.7 percent of its students came from the central Russian region). All other academies exhibit significantly less correlation with 
their "home" seminaries: 27.8 percent of Kiev Academy's future bishop students had attended a Ukrainian seminary, 20.9 percent of St. Petersburg Academy's students were graduates of Northwestern seminaries. This shows, to reiterate, that a high level of regional mobility was part and parcel of bishops' lives already during their education.

From 1871 until 1917 the prelates-to-be came from seminaries scattered over the entire Russian Empire, reflecting the pronounced trend of geographical diversification which has already been noted as a characteristic feature of the episcopate's regional origins during this period. Thus the central Russian seminaries furnished only 29.0 percent, two-thirds of the proportion they had supplied between 1811 and 1870 . Northwestern seminaries graduated 17.0 percent of the future hierarchy, Ukrainian seminaries 14.7 percent, and Blacksoil institutions 13.8 percent. Smaller numbers attended seminaries in various areas: 8.5 percent in towns on the Volga and 5.4 percent in Siberia, which had been a notoriously difficult region to attract priests to and recruit bishops from. Confirming the hierarchy's rising heterogeneity, Kazan' Academy on the Volga emerged from the shadow as a first-rate institution and graduated an impressive 19.1 percent of the episcopate, though still significantly less than St. Petersburg (30.7 percent), Kiev (26.3 percent), and Moscow (23.9 percent) Academies.

In theory, geographical diversification should have made for an episcopate more familiar than ever with the problems and aspirations of the parish clergy at the grass-roots level in even the remotest stretches of the Empire. In practice, however, the prelates ordained between 1871 and the end of the ancien régime experienced a hitherto unknown degree of geographical mobility during their education, reinforcing their separateness from both parish clergy and lay society. At Kiev Academy more students had been enrolled in seminaries in the Blacksoil region (34.4 percent) than in the Ukraine (30.2 percent) and at St. Petersburg Academy more students came from central Russian seminaries ( 35.3 percent) than from the Northwest (32.4 percent). Kazan' in the Volga region hosted the academy with the most diverse student body: 15.8 percent were graduates of Siberian seminaries, 13.2 percent of central Russian and Volga region seminaries respectively, and 7.9 percent of Northwestern institutions, to mention the largest contingents. Only Moscow Academy with its 65.0 percent central Russianeducated student body was anomalous.

Thus two features stand out in the composition of the future prelates as the ancien régime drifted towards revolution: first, by the early nineteenth century the bishops came to represent all parts of the vast Empire, a development which signaled an end to Great Russian hegemony in education. Second, rather than attending their "home" academy, growing numbers of seminary graduates entered one of the four academies which was remote from their seminary's location. The seemingly paradoxical result of the interplay of these two processes was an episcopate which, as an aggregate group, should have theoretically been wellinformed about the troubles besetting parish clerics in such disparate locations as Siberian Tomsk, Georgian Tiflis, and Ukrainian Khar'kov dioceses, but instead grew increasingly alien from the very estate it came from, for it received an élite education often far away from home, setting it apart from the rest of society and enhancing its cohesion. It only follows that a seminarian's everyday life and the contents of his education were of prime importance and deserve close scrutiny. 
On the level of everyday experience, a seminary education subjected a student to years of intense selection on several planes. The curriculum itself was structured in such a way that each year posed an increasingly difficult challenge, which most students were unable to confront; as a result, many students repeated a class, compounding the problem of overcrowding and leading to an extremely detrimental age composition in a given form, or else they dropped out of the seminary.

The dilemma of seminary education was its emphasis on Latin. From the inception of widespread seminary education in the 1750s, the Latinized "learned monk" bishops had prevailed over other interest groups in designating Latin as the language of instruction and centering the entire curriculum around it. ${ }^{25}$ Seminary education was divided into four segments, initial preparatory school being the only one which offered some Slavonic. From then on-from elementary school to advanced Latin school to the final school of philosophy and theology - Latin was the language and general focus of instruction. Coming from parish clergy backgrounds in which Latin was of little use (priests preached in Russian and recited the liturgy in Church Slavonic), most students never went beyond the level of elementary school. ${ }^{26}$

Partly due to such minor curriculum adjustments as the tentative inclusion of Russian and the abandonment of some derivative textbooks in 1760, but primarily because by the late 1760 s a full course of study had de facto become a prerequisite for appointment to a parish, more students now finished the seminary. Nevertheless, the two aims of seminary education, namely the mass training of future clerics for the reality of parish life and the formation of a (numerically minuscule) episcopal élite, continued to clash as bishops myopically superimposed their own type of education on the entire estate. Not surprisingly, prelates vehemently opposed the recommendation of the Reform Commission of Ecclesiastical Schools (1814-1839) that Russian replace Latin as the language of instruction and that the seminary curriculum be generally more geared to the army of future parish priests. Evidence suggests, however, that Russian had practically superseded Latin by the 1840 s. ${ }^{27}$ Yet most hierarchs, who still went through the Latin-oriented academies, defended Latinized instruction of the parish clergy until the twilight of the Tsarist Empire. And it was the group of priests who had become the first beneficiaries of the more pragmatic, anti-scholastic education, that was at the forefront of clerical reform movements in the 1860s.

No less important than what was being taught in the seminary is how and in what circumstances it was being taught. Rote memorization was the most vexing problem, compounded by bleak seminary finances which effected a shortage of qualified teachers, overcrowding, a lack of teaching materials, and facilities in a state of utter desuetude. Students lived under conditions hazardous both to their physical and mental health. Infectious diseases wreaked havoc among them, malnourishment was the rule rather than the exception, alcoholism and sexual escapades a fact of life. Typically, a report on Smolensk seminary cited that "many pupils (including both those with and without stipends), at all levels of the seminary, have been exposed for drunkenness, unruly conduct, insolence, and self-willed behavior; some were caught playing cards for money, others were apprehended for theft, and still others were found to be indifferent to services or given to sloth."28 It was not long until Russia's authorities took notice of seminarians, instigating the secret Third Section of the police to report, for 
example, that "pupils of the Perm' seminary constantly swim [in public], provoke unseemly attention by their immorality, by their vulgar talk (which is laced with the most indecent and coarse expressions), and by the time spent with women of ill-repute in nearby dwellings, where they give themselves up to various vices." 29

Moreover, physical violence was an integral part of the seminary experience. Notoriously brutal punishments by instructors instilled perhaps less fear than the student body's own rigid pecking order, in which older students dominated younger ones. ${ }^{30}$ One ex-seminarian soberly remarked, "when I graduated from the seminary, I counted the comrades who had studied with me since the second form: of 123 pupils, 7 remained," giving ample testimony to the seminary experience as a process of intense weeding out. ${ }^{31}$ The episcopate constituted a Darwinian selection in several respects. First, its health was exceptionally strong, for the graduates who later became bishops had best survived physical attacks from teachers and fellow students as well as the onslaught of various diseases. The episcopate's life expectancy was extraordinarily high: the 388 prelates whose data we have on average reached the age of sixty-five. ${ }^{32}$ More important, bishops were the psychologically fittest who emerged on top in the rugged social environment of the seminary. Their often tyrannical domination over the parish clergy was but an extension of a power struggle in which they had emerged victorious during their formative years as seminarians already. In other words, Russia's prelates were that segment of the student body, which, in an atmosphere of cruelty, had proven most adapted to and adept at cruelty. Finally, the bishops comprised a selection that made the best academic advance in these circumstances, enabling them to enter one of the four élite academies.

\section{From Academy to Ordination: Pre-Episcopal Career Patterns}

Much more than seminaries, academies fostered analytical thinking, theological training, and preparation for effective homilies. Their physical state was excellent compared with that of seminaries and their teachers constituted $\mathrm{Or}$ thodoxy's theological élite. Formally academy and secular university were on equal par. In short, the academy's explicit purpose was to produce a well-rounded Church élite. ${ }^{33}$

After graduation from the academy a fairly uniform career leading up to consecration as a bishop lay ahead of most students. Typically it included appointments in lower-level ecclesiastical education, then administrative positions in seminary and academy education often coupled with-ex officio and largely nominativeabbot functions at monasteries, and finally came appointment as bishop to a vacant diocese. Nevertheless, important changes occurred in these patterns.

The requirement for becoming a bishop was tonsure (postrizhenie), the ceremony during which the future prelate took his monastic vow. Precisely when he received his tonsure was a controversial question throughout the Imperial Russian era. In 1724 a Synodal "Resolution on Monasticism" demanded that academy graduates engaged in ecclesiastical education be at least thirty years old when taking their monastic vows. ${ }^{34}$ Yet from then on until the early nineteenth century academy graduates on average were consistently younger than thirty years at tonsure. Only in 1832 a Synodal ukaz legitimized the uncanonical under-age tonsure. That $1832 \mathrm{ukaz}$ also permitted the tonsure of widowed 
priests without academy degrees. Interestingly, it was not until this ukaz that the pool from which hierarchs were recruited, "learned monks"-that is, it will be recalled, the phenomenon of Church educators who took monastic vows but never lived in a monastery - were de iure relieved of their duty to serve in a monastery and thereby officially accommodated in canon law. ${ }^{35}$ The episcopate's average age at tonsure increased considerably in the 1870s and remained high until 1917. The influx of widowed parish priests explains this trend. (When the full impact of the Church reforms of the 1860s became felt, a decline of those who took monastic vows in the academy actually caused a shortage of potential bishops. Consequently widowed parish priests increasingly received tonsure and were drafted into the episcopate.)

A pre-episcopal career sometimes began before a student received his degree from the academy, since some upper-level academy students were offered teaching positions at a nearby district school or seminary. This trend became increasingly pronounced during the two centuries under concern. Thus the average age of bishops at their first pre-episcopal job continually declined from thirty years in the Post-Petrine era to twenty-seven years under Catherine to twenty-five years during Nicholas I's reign. As a result of the influx of widowed parish priests it increased slightly under Alexander III (25.5 years) and was at 25.1 years during Nicholas II's reign.

From their first pedagogical function the "learned monks" customarily were appointed to an administrative inspector or rector post at the district school or seminary they were teaching at. ${ }^{36}$ Nomination as rector of one of the four academies, often coupled with some teaching duties, constituted the next logical step on the career ladder. As a rule the rector positions at both seminary and academy were connected with nominal appointments as abbots of an adjacent

Figure 4

From Academy to Ordination

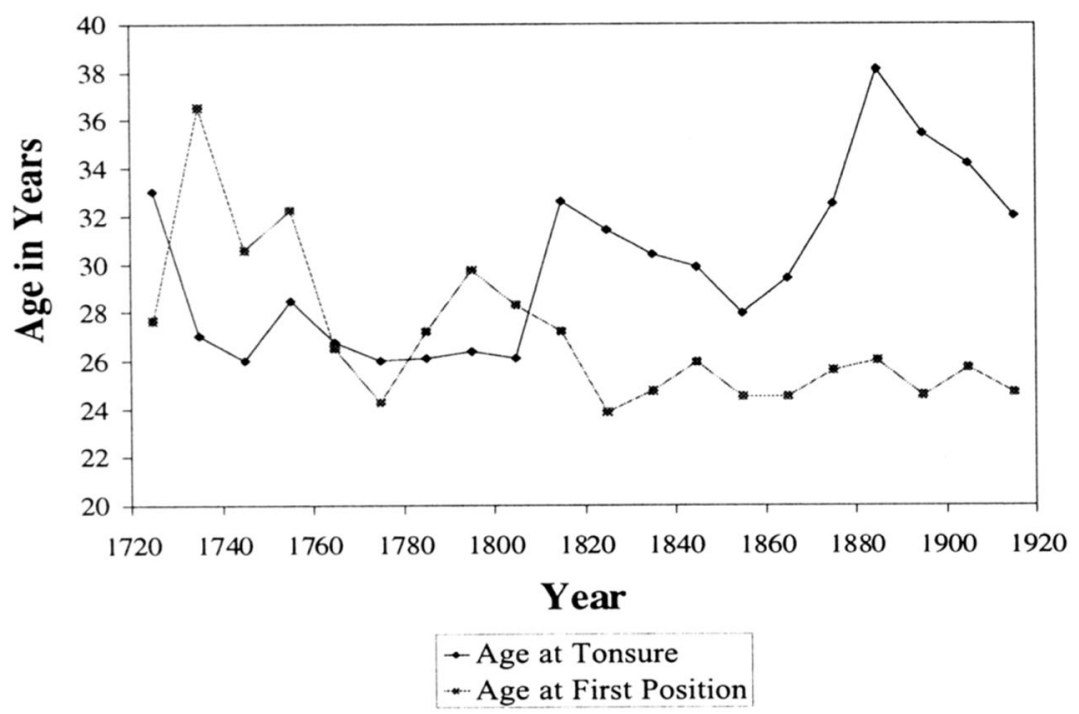


Figure 5

Number of Pre-Episcopal Positions

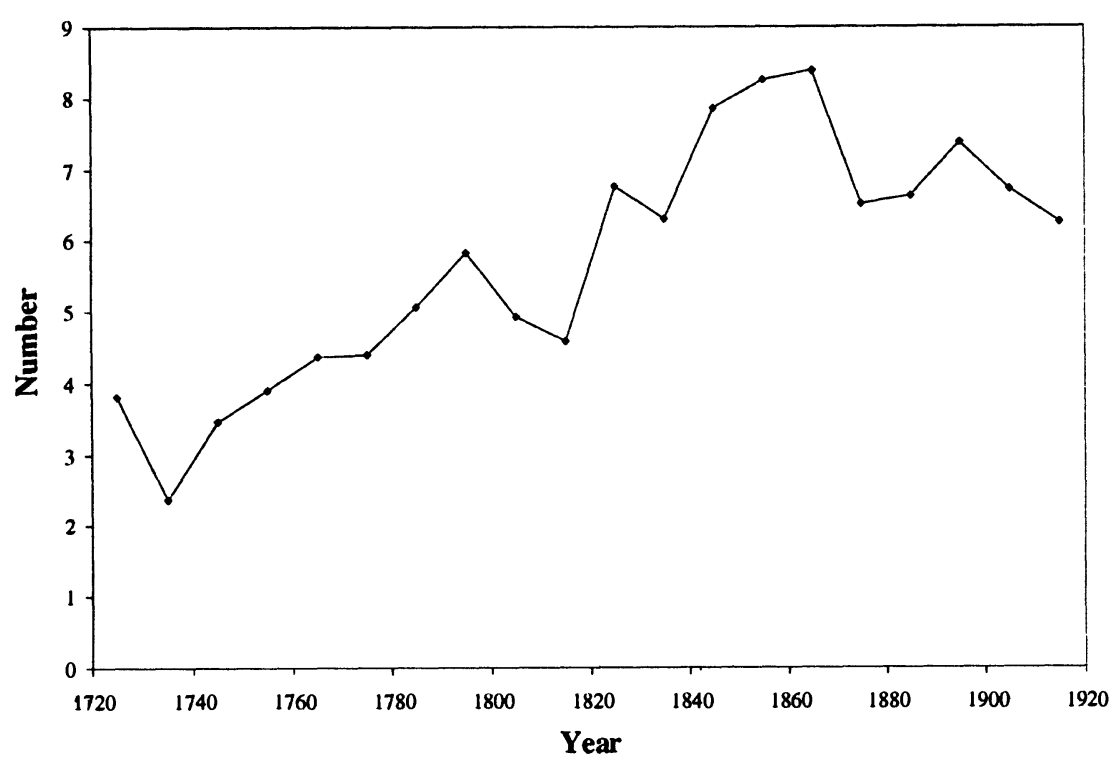

monastery. Although the sequence of jobs was quite fixed, considerable regional mobility was an integral part of the pre-episcopal experience, too. Inspectors and rectors were transferred frequently from one seminary to another, sometimes even to Orthodox missions in foreign countries, and by the time they were ordained as bishops they had held multiple jobs in disparate parts of the Empire.

The frequent transfers of inspectors and rectors had disastrous consequences for the relations between clergy and learned monks. As the conservative intellectual P. S. Kazan'skii, whose brother was a bishop, complained: "With the frequent change of rectors [who leave to become bishops], the seminary (which depends entirely upon the rector) cannot be in a good condition. The rector regards himself as a guest and therefore has no incentive to be much concerned with the seminary. [Even] if he did wish to be active, he would not have time to become well acquainted with the needs and wants of the seminary, the teachers, and pupils. ( ... ). In all my life, I have never seen a decent rector: either he is a despot, or a fool, or a capricious egotist interested only in himself and his promotion." ${ }^{37}$ The negative impact of these transfers was felt all the more acutely after the educational reform of 1814, when much of the prelate's power in seminary affairs devolved upon the rector. Resentment of the learned monks also had an important socioeconomic dimension, for they received money from their nominal abbot appointments in addition to their regular salary. Furthermore, an ukaz of 1799 decreed that learned monks in pedagogical positions be awarded a portion of the city cathedral's revenues. And learned monks were permitted to bequeath their belongings to relatives or others, whereas the possessions of 
monastic monks were inherited by the state. This created a sharp disparity in wealth between learned monks on the one hand and monastic monks, regular (non-monastic) seminary or academy educators, and clerics on the other. ${ }^{38}$

\section{The Prelates: Episcopal Careers and the Problem of Diocesan Transfers}

The process of episcopal selection itself was subject to change in the course of the two centuries under consideration. In the advent of an episcopal opening, bishops in Pre-Petrine Russia convened in Moscow, where each prelate proposed a candidate from his diocese. By consensus the assembled hierarchs then drew up a list of three, which was handed to the patriarch, who in turn selected one and consulted the Tsar for approval. Subsequently the chosen candidate was consecrated during a mass celebrated by prelates and patriarch. Peter broke radically with this custom and made a practice of issuing an ordinary ukaz announcing the episcopal nomination of his choice. A new regulation in 1725 provided for the selection of two candidates by the Holy Synod, which left the final choice to the Emperor. In reality, however, the Synod often selected a larger number of candidates and submitted its choice of a favorite to the Tsar, who sometimes overrode the Synod's decision. This system remained in place until 1917.39

In the perception of parish priests, lay folk, and critical observers the overriding cause for the estrangement between hierarchy and clergy was the Synodal habit of transferring bishops from one diocese to another. Against the backdrop of this fundamentally important perception, in the following I trace the causes and dynamics of these transfers and examine their empirical validity. Contrary to popular perception, frequent episcopal transfer was not a heinous means devised by nineteenth-century procurators to award or punish prelates, but rather had its historic roots in the second half of the sixteenth century (prior to that, transfer was unknown). These transfers, to be sure, were rare; yet it bears noting that transfer was neither a Petrine nor a nineteenth-century invention. ${ }^{40}$

Clerics' main charge was that frequent transfer prevented a bishop from immersing himself in the special problems of the local clergy in his diocese; either from disinterest or resignation, he did not take it upon himself to inspect parishes at the grass-roots level through visitations, as his predecessors in Muscovite times had done-complained parish priests. ${ }^{41}$ The Procurator and Synod, on the other hand, in nineteenth-century Russia came to view episcopal transfer as an important instrument of social mobility for the hierarchy, rewarding a bishop for distinguished performance with transfer to a more desirable diocese (usually an old, established one in central Russia) and punishing the unruly or unsatisfactory prelate with transfer to a difficult diocese far from the center. ${ }^{42}$ From the Synodal perspective transfer thus constituted a distinctly Modern meritocratic principle ${ }^{43}$ Moreover, through transfer bishops gained a more inclusive picture of the Empire. ${ }^{44}$

The empirical evidence suggests that bishops were indeed transferred more and more often, especially in the latter part of the nineteenth century. To be sure, a change of diocese every five years was detrimental to a bishop's ability of gaining an in-depth understanding of circumstances that differed vastly from region to region, and then see to it that the changes that he ushered in were actually carried through. 
Figure 6

$\begin{array}{lcc}\text { Reign } & \begin{array}{c}\text { Average Number } \\ \text { of Dioceses }\end{array} & \begin{array}{c}\text { Average Number of } \\ \text { Years in a Diocese }\end{array} \\ \text { Post-Petrine } & 1.86 & 8.82 \\ \text { Catherine II } & 2.55 & 8.39 \\ \text { Paul I } & 3.17 & 5.75 \\ \text { Alexander I } & 2.86 & 6.67 \\ \text { Nicholas I } & 3.04 & 5.21 \\ \text { Alexander II } & 3.31 & 7.34 \\ \text { Alexander III } & 2.24 & 2.35 \\ \text { Nicholas II } & 4.05 & 5.50\end{array}$

Most important, however, was the negative impact of episcopal mobility on the normative, spiritual relationship between clergy and hierarchy. Canon law had expressly condemned episcopal transfer, demanding that a bishop stay in the diocese to which he had been appointed in the name of God and properly fulfill his duties in the spiritual marriage between his diocese and himself. Clergy and laity thus perceived transfer as the sundering of a bond that was not to be broken, as a divorce in a system of marital norms that knew no such option. ${ }^{45}$

It came as no surprise that the clericalist reform movements, which had been gaining momentum from the middle of the nineteenth century, propagated a radical change in customary episcopal recruitment practices: parish priests rather than learned monks should comprise the episcopate, since learned monks lacked this-worldly experience and had, in fact, never been intended for administrative tasks after taking ascetic vows. ${ }^{46}$ Belliustin, the unruly village priest whose manifesto loomed large in nineteenth-century clericalism from below, essentially declared war on the learned monks by making them responsible for most everything that was amiss in the clergy. Nor did he stop short of suggesting that their celibacy-the very distinction that made a world of difference between them and parish priests (apart from education) - was a mere sham. Belliustin thus wrote a satirical list of "canons," intended to regulate the behavior of learned monks; one point on the list recommended that "because it is impossible to have one wife, one may have two or three 'nieces,' as one likes," and another read as follows: "For a true monk everything is permissible, but if he should do something really horrendous (such as strangle or stab his mistress), then keep everything as secret as possible and use all your powers to defend him before the courts." 47

The secondary literature ignores the question of episcopal celibacy. Whether or not prelates kept mistresses is a question worth pursuing; more important, however, is the parish clergy's perception of episcopal celibacy. The fact that a village priest would publicly doubt the celibacy of a bishop is an indication to what extent relations had deteriorated.

To summarize, the frequent transfer of bishops was primarily a further strain on episcopal-clerical relations rather than an impediment to efficient diocesan administration. With a superior education, an Empire-wide perspective, and skilled staff at his beck and call, a prelate could potentially manage his diocese with great success, even for a restricted period of time. It must also be emphasized that bishops did not transfer voluntarily, let alone out of mauvaise foi, but were 
at the mercy of the authorities in St. Petersburg. On the other hand, because of their early parting of ways with the parish clergy bishops were insensitive to the historical and religious dimensions of their relationship with priests. When interacting with parish priests, prelates were said to display distant "formalism," destroying the time-honored bonds of familiarity, based upon notions of spiritual patriarchy and marriage. These concepts had governed the interaction between bishops and priests until the socializing seminary and academy experiences made their full impact in the late eighteenth century.

\section{Comparisons and Conclusion}

The Russian Orthodox episcopate thus coalesced into a fairly cohesive élite group in the early nineteenth century. During the eighteenth century different regional and social backgrounds still played an important role in shaping a bishop's identity and his political behavior. While Peter the Great had consciously turned to Ukrainian bishops and while Catherine the Great had reverted to Great Russian candidates (even if these were graduates of the new, Petrine institutions of ecclesiastical education), in the nineteenth century bishops came from all over the Russian Empire. Likewise, from about the mid-eighteenth century onward almost all prelates were from the clerical estate, and the difference in social background stopped being the contested issue that it had been during the first half of the eighteenth century. The seminary became the principal site for stratification. There, future bishops parted ways with future parish priests. The former not only survived in the difficult conditions of the seminary but also managed to be admitted to an ecclesiastical academy. Future bishops increasingly moved through the Empire-from home to seminary, from seminary to academy, and from one pre-episcopal position to another. Their frequent transfers as bishops between dioceses were therefore nothing unusual to them. The parish clergy and laity, however, perceived precisely these transfers to be the cause for the rift between themselves and the bishops, even if this rift had already occurred in the seminary.

A comparison of the Russian Orthodox bishops with bishops in the West must begin with fundamental differences. Most glaringly, the social origins of Catholic bishops were structurally different, since Catholic clergymen were prohibited to marry while Russian Orthodox priests were free and-given their dependence on fees for rites and the parish garden for food-indeed structurally encouraged to do so. And in countries like France, the legal relationship between monarchy and Church remained different insofar as the monarchy retained the legal right to appoint and transfer bishops, a right it made use of, while in Russia between 1725 and 1917 this right devolved upon the Holy Synod (the Emperor's privilege to veto episcopal appointments notwithstanding). De facto, particularly, the transfer of prelates was completely in the hand of the Holy Synod.

Nonetheless, during the eighteenth and nineteenth centuries the episcopate in many Western European countries remained a closed élite, too. In England, the Anglican episcopate actually reversed the eighteenth-century trend of social mobility that had allowed increasing numbers of middle class members to become prelates. As has recently been shown, the image of a remodeled nineteenth-century episcopate, made up of working-class graduates from the 
open institutions of élite education, is a Whiggish myth. ${ }^{48}$ Once established, the middle class retained control over the episcopate. In fact, the Anglican episcopate exhibited a greater degree of social mobility during Henry VIII's reign than under Queen Victoria. ${ }^{49}$ In Absolutist France, the episcopate was almost exclusively noble in origin, and often exhibited familial bonds with the royal family. ${ }^{50}$ Only after 1830 did the episcopate's social composition radically change, with less than five percent of bishops from noble background by the end of the century. ${ }^{51}$ In the Catholic parts of the eighteenth-century Netherlands, sixty percent of the episcopate was noble in origin. ${ }^{52}$ In Austria during 16481803 nearly the entire episcopate was from the nobility. ${ }^{53}$ And in the Catholic German lands during the eighteenth century, the two upper ranks of the episcopate (Fürstbischöfe and Weihbischöfe) were almost completely noble in origin while the lowest rank (Generalvikare) underwent a process of "refeudalization" after a period of relative openness to the middle estates during the sixteenth and seventeenth centuries. ${ }^{54}$ Therefore it is interesting to note that the closure of the Russian episcopate to anyone but clergy sons in the late eighteenth century was analogous to developments in other parts of Europe, where the episcopate also came to rely on a single social group. The Anglican episcopate, for instance, during the same period ceased being a relatively open and socially mobile group, despite the fact that England was the paragon of a Modern class society, not a pre-Modern system of social estates.

The question of episcopal transfers, too, was a problematic issue all over Europe. During the Early Modern period already, the long diocesan tenures of French prelates were seen as the ideal in the Catholic world and the Italian and Spanish cases as deviations from that ideal. While the frequent transfers in seventeenth-century Italy and especially Spain, where the "average duration of episcopal tenure per diocese was only slightly more than seven years," generated much criticism, a French bishop averaged about two decades per diocese. ${ }^{55}$ England was similar to France: the tenures of Anglican bishops in their dioceses were also remarkably stable between 1700 and $1900 .^{56}$ What the Russian example contributes to the discussion of episcopal transfers in Western Europe is that these need not necessarily and inevitably have a negative impact on the efficiency of diocesan management, even if the clergy and laity's perception held this to be the case. Contrary to Joseph Bergin's assessment that episcopal transfers always hamper the efficiency of the episcopate, the Russian case demonstrates that this is not necessarily true. In fact, it can be argued that the practice of diocesan transfers was one of the genuinely Modern features of Imperial Russia. A governing board of the Church made up of bishops, the Holy Synod, with little to no interference from the monarchy, used transfer as a meritocratic instrument to manage its highly educated episcopate, a bureaucratic élite unified by a common esprit de corps. Indeed, this practice was not so dissimilar from the Bolshevik politburo's deployment of élite party cadres, who were also frequently transferred according to meritocratic and utilitarian considerations. Only the practice of diocesan transfers violated medieval religious notions of spiritual marriage between bishop and parish clergy and bishop and laity.

Department of History

Berkeley, CA 94720 


\section{Appendix 1}

\section{Geographical Origins}

\begin{tabular}{|c|c|c|c|c|c|c|c|c|c|c|c|c|c|c|c|c|c|}
\hline \multirow[t]{2}{*}{ Reign } & \multicolumn{3}{|c|}{ I } & \multicolumn{3}{|c|}{ II } & \multicolumn{2}{|c|}{ III } & \multicolumn{2}{|c|}{ IV } & \multirow[t]{2}{*}{ V } & \multirow[t]{2}{*}{ VI } & \multirow[t]{2}{*}{ VII } & \multirow[t]{2}{*}{ VIII } & \multirow[t]{2}{*}{$I X$} & \multirow{2}{*}{$\begin{array}{c}N \\
\% \text { of } \\
\text { total }\end{array}$} & \multirow[t]{2}{*}{ Total } \\
\hline & A & $B$ & C & $A$ & $B$ & C & A & $B$ & $A$ & $B$ & & & & & & & \\
\hline \multirow[t]{2}{*}{ Post-Petrine } & 3 & 5 & 1 & 21 & & & 1 & 2 & & 1 & 1 & & & 7 & 1 & 43 & 91 \\
\hline & $7.0 \%$ & $11.6 \%$ & $2.3 \%$ & $48.8 \%$ & & & $2.3 \%$ & $4.7 \%$ & & $2.3 \%$ & $2.3 \%$ & & & $16.3 \%$ & $2.3 \%$ & & \\
\hline \multirow[t]{2}{*}{ Catherine II } & 4 & 13 & & 13 & & & 1 & 1 & & & & & 1 & & 3 & 36 & 63 \\
\hline & $11.1 \%$ & $36.1 \%$ & & $36.1 \%$ & & & $2.8 \%$ & $2.8 \%$ & & & & & $2.8 \%$ & & $8.3 \%$ & & \\
\hline Paul I & 3 & & & 4 & & & & & & 1 & & & & & & 8 & 13 \\
\hline \multirow{2}{*}{ Alexander I } & 6 & 16 & & 3 & & & 3 & 1 & & & & & 1 & & & 30 & 62 \\
\hline & $20.0 \%$ & $53.3 \%$ & & $10.0 \%$ & & & $10.0 \%$ & $3.3 \%$ & & & & & $3.3 \%$ & & & & \\
\hline \multirow[t]{2}{*}{ Nicholas I } & 8 & 26 & & 15 & & & 11 & 1 & 1 & 2 & 2 & & 4 & & & 70 & 90 \\
\hline & $11.4 \%$ & $37.1 \%$ & & $21.4 \%$ & & & $15.7 \%$ & $1.4 \%$ & $1.4 \%$ & $2.9 \%$ & $2.9 \%$ & & $5.7 \%$ & & & & \\
\hline \multirow[t]{2}{*}{ Alexander II } & 16 & 42 & & 13 & 3 & 1 & 27 & 7 & 2 & 2 & 1 & 2 & 7 & & 1 & 124 & 124 \\
\hline & $12.9 \%$ & $33.9 \%$ & & $10.5 \%$ & $2.4 \%$ & $0.8 \%$ & $21.8 \%$ & $5.6 \%$ & $1.6 \%$ & $1.6 \%$ & $0.8 \%$ & $1.6 \%$ & $5.6 \%$ & & $0.8 \%$ & & \\
\hline \multirow[t]{2}{*}{ Alexander III } & 13 & 29 & 1 & 8 & 3 & 1 & 13 & 7 & & 2 & 3 & & 1 & & & 81 & 88 \\
\hline & $16.0 \%$ & $35.8 \%$ & $1.2 \%$ & $9.9 \%$ & $3.7 \%$ & $1.2 \%$ & $16.0 \%$ & $8.6 \%$ & & $2.5 \%$ & $3.7 \%$ & & $1.2 \%$ & & & & \\
\hline Nicholas II & 34 & 38 & 1 & 26 & 4 & 4 & 19 & 25 & & 5 & 4 & 2 & 7 & 2 & 2 & 173 & 200 \\
\hline Imperial Russia & 87 & 171 & 3 & 103 & 10 & 6 & 75 & 44 & 3 & 13 & 11 & 4 & 21 & 9 & 7 & 567 & 731 \\
\hline Total & $15.3 \%$ & $30.2 \%$ & $0.5 \%$ & $18.2 \%$ & $1.8 \%$ & $1.1 \%$ & $13.2 \%$ & $7.8 \%$ & $0.5 \%$ & $2.3 \%$ & $1.9 \%$ & $0.7 \%$ & $3.7 \%$ & $1.6 \%$ & $1.2 \%$ & & \\
\hline
\end{tabular}

Key to regions: I. Industrial: A-North and Northwest (Arkhangel'sk, Olonets, Vologda, St. Petersburg, Novgorod, Pskov, Smolensk, Tver'); B-Central-industrial (Iaroslavl', Moscow, Vladimir, Kostroma, Kaluga, Nizhnyi Novgorod, Tula, Riazan'); C-Belorussia. II. Southern Agrarian: A-Ukraine (Poltava, Khar'kov, Chernigov, Kiev, Volyn'ia, Podol'ia); B-Southern Steppes (Kherson, Ekaterinoslav, Tauridia); C-Northern Caucasus (Don oblast'). III. Central Agrarian: A-Blacksoil (Voronezh, Kursk, Orel, Tambov); B-Volga (Astrakhan', Saratov, Samara, Penza, Simbirsk, Kazan', Viatka, Ufa). IV. Eastern Agrarian: A-Urals (Perm', Orenburg); B-Siberia. V. Baltics. VI. Bessarabia. VII. Georgia. VIII. 


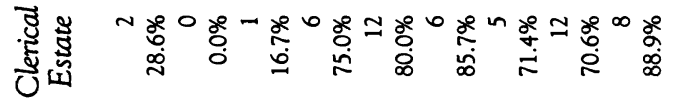

$$
\begin{aligned}
& \text { 营 }
\end{aligned}
$$

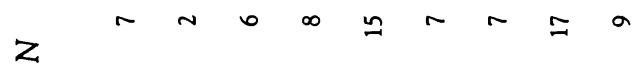

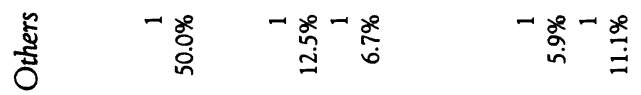

$$
\begin{aligned}
& \text { 莺 }
\end{aligned}
$$

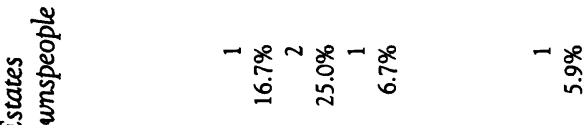

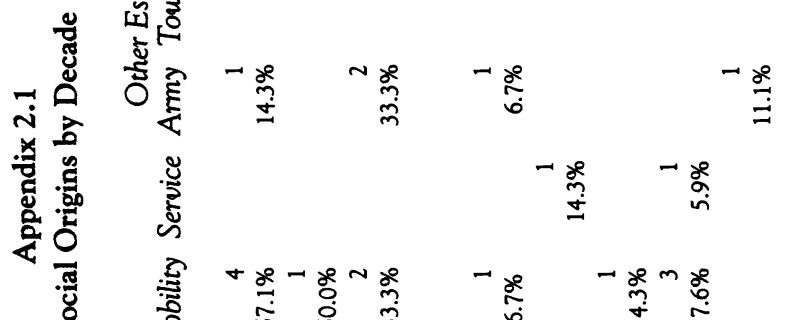

$$
\begin{aligned}
& \text { 焉 }
\end{aligned}
$$

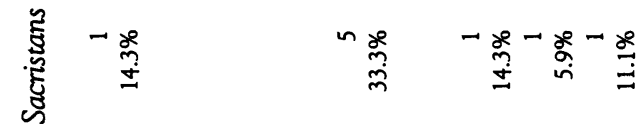

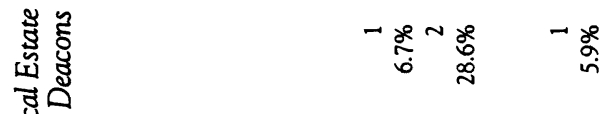

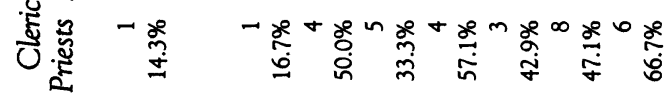

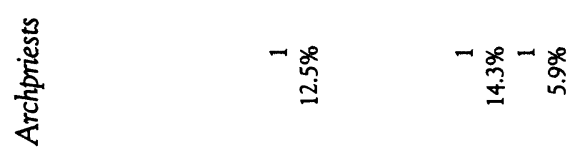

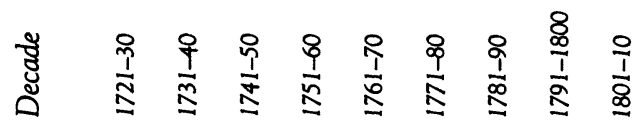




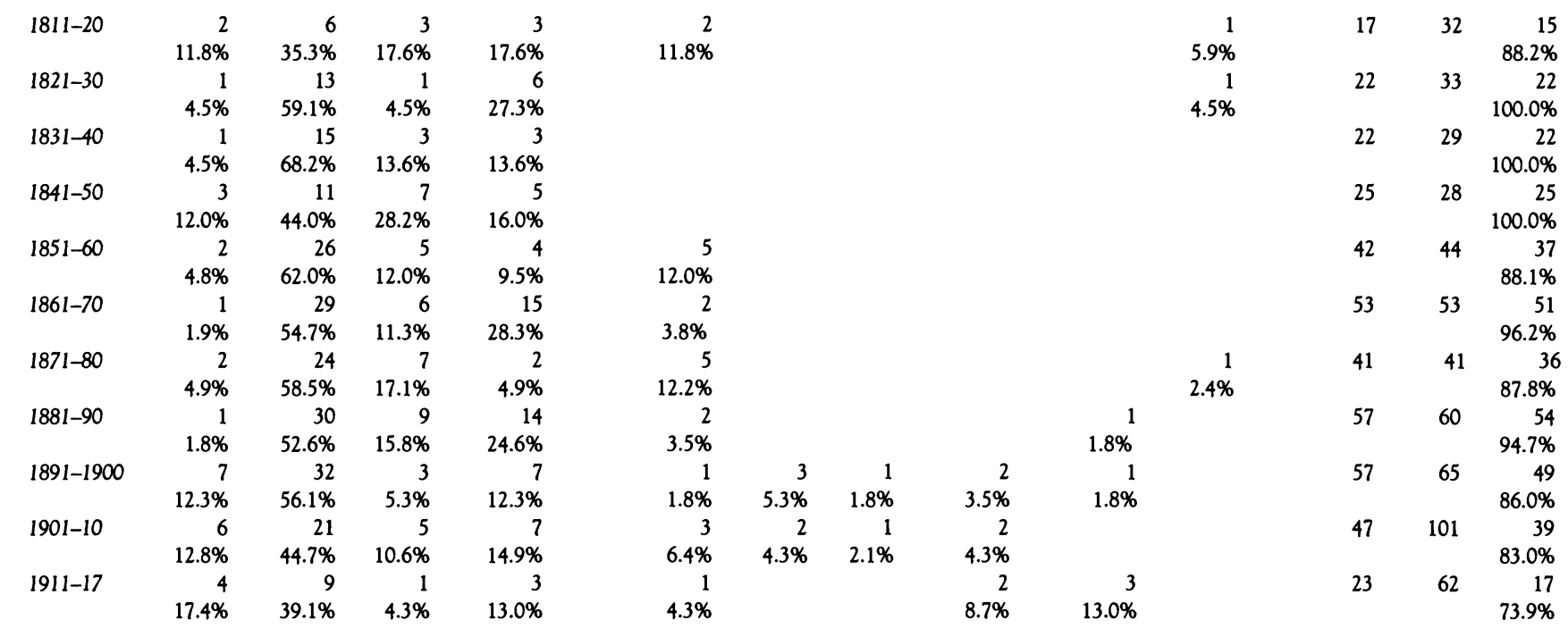




$$
\begin{aligned}
& \text { 胥芯 士 } \\
& \text { 胥 }
\end{aligned}
$$

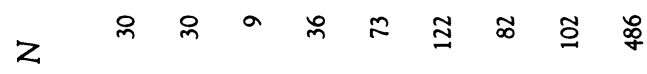

$$
\begin{aligned}
& \text { 总 } \\
& \text { हुँ }
\end{aligned}
$$

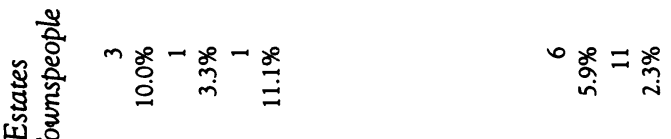

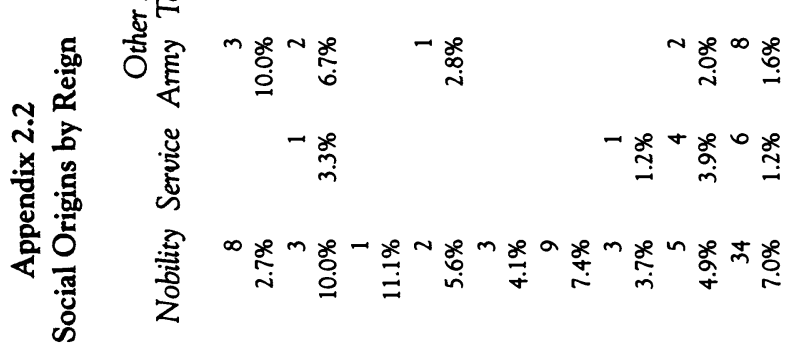

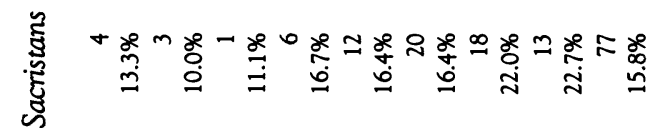

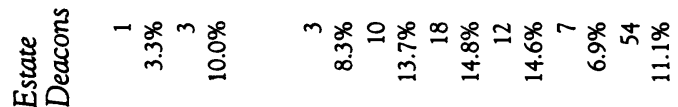

胥岁

產

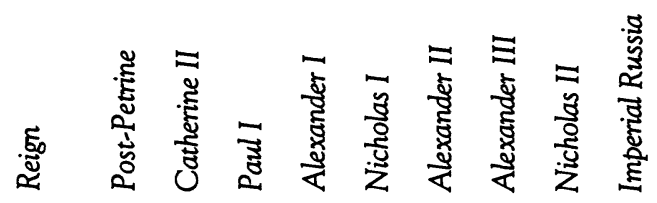




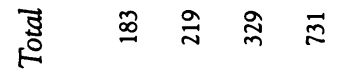

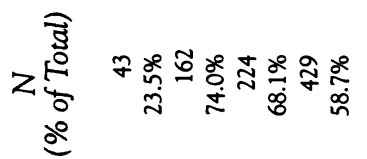

$$
\begin{aligned}
& \text { \ }
\end{aligned}
$$

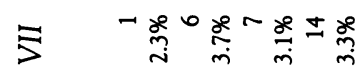

$$
\begin{aligned}
& 5 \quad \text { m } \\
& >\quad \text { - }
\end{aligned}
$$

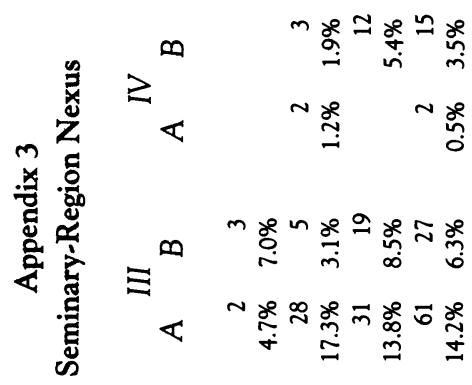

$$
\begin{aligned}
& 0
\end{aligned}
$$

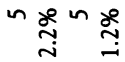

$$
\begin{aligned}
& =\infty \quad m \text { 울 } \frac{x}{m} \text { 윽 }
\end{aligned}
$$

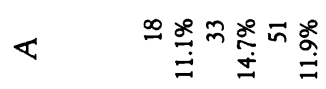

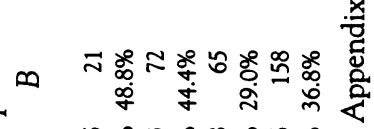

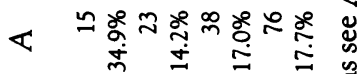

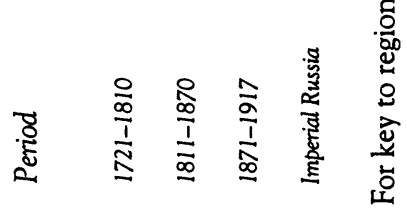




\section{Appendix 4 \\ Ecclesiastical Academies}

$1721-1810$

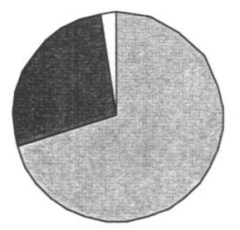

$1811-70$

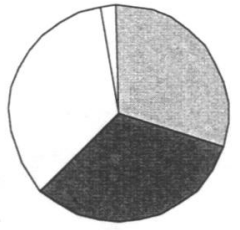

$1871-1917$

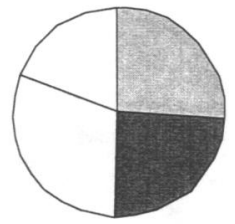

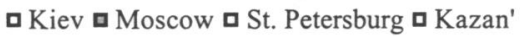

$\begin{array}{lccrrrrr}\text { Period } & \text { Kiev } & \text { Moscow } & \begin{array}{c}\text { St. } \\ \text { Petersburg }\end{array} & \text { Kazan' } & \text { N } & \begin{array}{c}\% \text { of } \\ \text { Total }\end{array} & \text { Total } \\ 1721-1810 & 56(70.0 \%) & 22(27.5 \%) & 2(2.5 \%) & & 80 & 43.7 \% & 183 \\ 1811-70 & 43(30.3 \%) & 45(31.7 \%) & 51(35.9 \%) & 3(2.1 \%) & 142 & 64.8 \% & 219 \\ 1871-1917 & 77(26.3 \%) & 70(23.9 \%) & 90(30.7 \%) & 56(19.1 \%) & 293 & 89.1 \% & 329 \\ \text { Imperial Russia } & 176(34.2 \%) & 137(26.6 \%) & 143(27.8 \%) & 59(11.5 \%) & 515 & 70.5 \% & 731\end{array}$

Appendix 5.1

Pre-Episcopal Careers by Reign

$\begin{array}{lcccccc}\text { Reign } & \text { A } & \text { B } & \text { C } & \text { D } & \text { E } & \text { F } \\ & & & & & & \\ \text { Post-Petrine } & 29.97(23) & 28.15(22) & 5.68(6) & 12.91(48) & 3.45(91) & 3.58(48) \\ \text { Catherine II } & 27.08(26) & 26.59(25) & 5.65(13) & 13.92(41) & 4.79(63) & 3.18(41) \\ \text { Paul I } & 27.70(4) & 24.67(6) & 4.06(3) & 11.64(9) & 6.38(13) & 2.17(9) \\ \text { Alexander I } & 26.74(28) & 30.24(31) & 8.72(20) & 16.17(48) & 5.11(62) & 3.37(48) \\ \text { Nicholas I } & 24.93(50) & 29.63(50) & 7.12(39) & 18.76(78) & 7.26(90) & 2.82(78) \\ \text { Alexander II } & 24.73(61) & 29.91(61) & 10.84(59) & 23.49(119) & 7.70(124) & 3.36(121) \\ \text { Alexander III } & 25.47(20) & 37.19(20) & 14.58(71) & 25.13(88) & 6.82(88) & 3.90(88) \\ \text { Nicholas II } & 25.14(190) & 33.71(188) & 13.59(123) & 18.13(192) & 6.73(200) & 4.49(193) \\ \text { Imperial Russia } & 25.61(402) & 31.66(403) & 11.73(334) & 19.30(623) & 6.25(731) & 3.71(626)\end{array}$

Key to table: A-average age in years at nomination to first pre-episcopal position. Baverage age in years at tonsure. C-average interval in years between $A$ and $B$. $D$-average total years in all pre-episcopal positions. E-average number of pre-episcopal positions. F-average number of years in one pre-episcopal position. Note: $\mathrm{N}$ in parentheses. 
Appendix 5.2

Pre-Episcopal Careers by Decade

$\begin{array}{lccrrrr}\text { Decade } & A & B & C & D & E & F \\ 1721-30 & 27.68(3) & 33.02(3) & 6.02(3) & 15.61(9) & 3.80(15) & 3.98(9) \\ 1731-40 & 36.52(2) & 27.02(1) & & 9.28(9) & 2.38(24) & 3.80(9) \\ 1741-50 & 30.53(7) & 25.99(6) & 7.01(1) & 13.32(15) & 3.48(23) & 3.34(15) \\ 1751-60 & 32.20(5) & 28.46(7) & & 11.98(8) & 3.90(20) & 4.18(8) \\ 1761-70 & 26.50(12) & 26.72(10) & 7.96(5) & 13.77(18) & 4.36(25) & 3.15(18) \\ 1771-80 & 24.28(7) & 26.01(5) & 5.13(4) & 11.57(10) & 4.40(15) & 2.48(10) \\ 1781-90 & 27.19(8) & 26.13(8) & 2.75(5) & 16.20(11) & 5.06(16) & 3.30(11) \\ 1791-1800 & 29.76(9) & 26.39(14) & 5.14(4) & 12.97(18) & 5.83(30) & 2.80(18) \\ 1801-10 & 28.29(8) & 26.11(10) & 5.53(4) & 16.78(10) & 4.93(15) & 3.39(10) \\ 1811-20 & 27.21(14) & 32.61(12) & 10.48(9) & 15.84(26) & 4.59(32) & 3.66(26) \\ 1821-30 & 23.86(16) & 31.41(18) & 6.86(19) & 16.55(28) & 6.76(34) & 2.76(28) \\ 1831-40 & 24.75(16) & 30.35(16) & 7.13(12) & 15.74(24) & 6.31(29) & 2.79(24) \\ 1841-50 & 25.92(15) & 29.83(15) & 6.90(11) & 19.60(26) & 7.86(28) & 2.67(26) \\ 1851-60 & 24.49(29) & 27.94(29) & 12.95(13) & 23.28(42) & 8.25(44) & 3.12(42) \\ 1861-70 & 24.49(24) & 29.39(24) & 8.44(27) & 23.39(52) & 8.38(53) & 2.94(52) \\ 1871-80 & 25.61(17) & 32.51(17) & 12.24(24) & 24.40(38) & 6.51(41) & 4.11(40) \\ 1881-90 & 26.02(10) & 38.08(10) & 14.28(50) & 25.59(60) & 6.63(60) & 4.13(60) \\ 1891-1900 & 24.53(47) & 35.47(47) & 15.17(48) & 21.74(65) & 7.38(65) & 3.07(65) \\ 1901-10 & 25.69(95) & 34.18(93) & 13.43(63) & 17.85(97) & 6.72(101) & 5.99(98) \\ 1910-17 & 24.68(58) & 32.00(58) & 12.69(33) & 17.46(58) & 6.26(62) & 3.02(58)\end{array}$




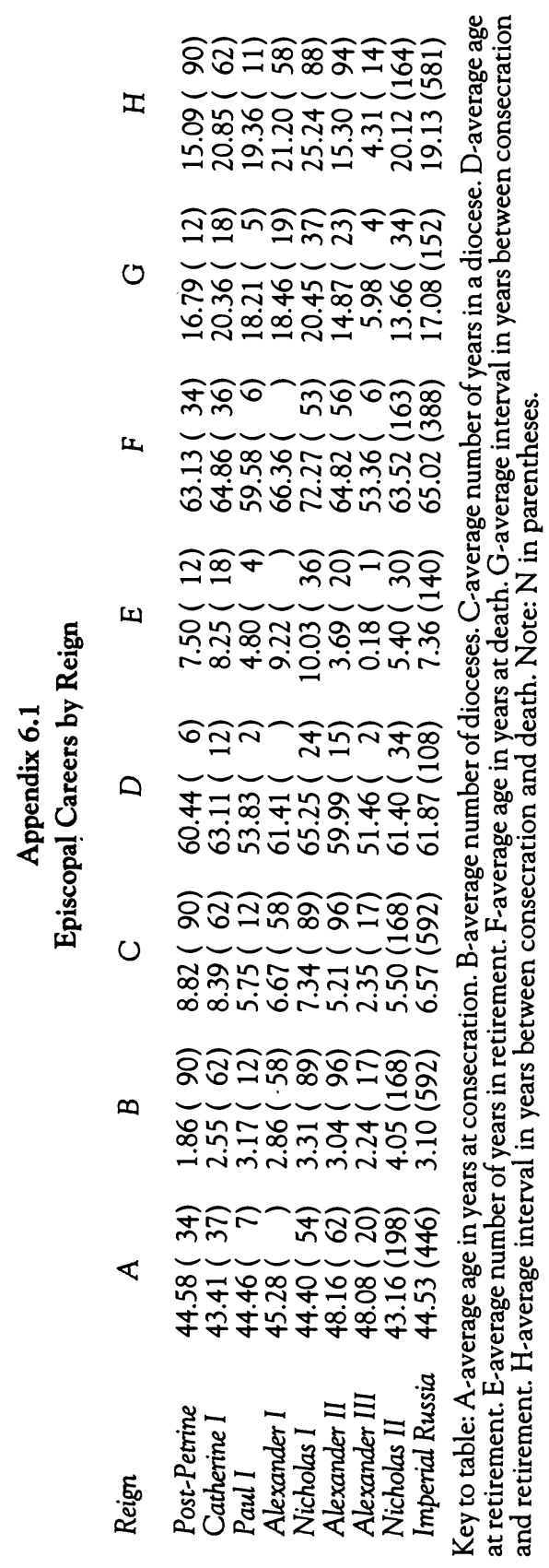


Appendix 6.2

Episcopal Careers by Decade

$\begin{array}{lcccccccc}\text { Decade } & A & \text { B } & \text { C } & D & E & F & G & H \\ 1721-30 & 48.58(5) & 2.07(15) & 8.71(15) & & 0.83(2) & 66.47(5) & 16.37(2) & 14.43(15) \\ 1731-40 & 43.34(3) & 1.87(23) & 7.53(23) & & 3.03(2) & 46.73(3) & 11.16(2) & 11.55(23) \\ 1741-50 & 43.36(9) & 2.13(23) & 7.80(23) & & 3.27(1) & 62.96(9) & 33.61(1) & 15.44(23) \\ 1751-60 & 46.05(9) & 1.45(20) & 11.82(20) & 60.17(4) & 9.41(5) & 69.07(9) & 13.60(5) & 18.02(20) \\ 1761-70 & 40.58(15) & 2.00(25) & 9.44(25) & 64.26(5) & 10.96(7) & 62.78(15) & 24.18(7) & 20.99(25) \\ 1771-80 & 39.31(9) & 2.57(14) & 9.66(14) & 53.45(3) & 9.43(5) & 63.81(8) & 11.44(5) & 23.34(14) \\ 1781-90 & 43.66(11) & 2.38(16) & 8.51(16) & 70.99(3) & 5.03(5) & 62.27(11) & 25.66(5) & 20.03(16) \\ 1791-1800 & 48.01(18) & 3.07(29) & 5.81(29) & 58.47(5) & 7.22(7) & 65.79(17) & 18.45(8) & 18.58(28) \\ 1801-10 & 43.92(10) & 2.93(15) & 6.82(15) & 55.13(4) & 15.81(4) & 66.25(10) & 14.85(4) & 21.02(15) \\ 1811-20 & 46.03(15) & 2.75(28) & 6.92(28) & 61.62(7) & 7.32(12) & 66.78(15) & 19.10(12) & 21.79(28) \\ 1821-30 & 44.12(20) & 3.18(34) & 6.32(34) & 67.94(9) & 7.78(12) & 68.39(20) & 22.33(12) & 22.50(34) \\ 1831-40 & 41.90(18) & 3.28(29) & 7.52(29) & 64.32(8) & 12.60(12) & 72.82(18) & 19.66(13) & 27.75(28) \\ 1841-50 & 46.56(15) & 3.59(27) & 8.17(27) & 64.21(7) & 9.76(13) & 75.84(14) & 22.09(13) & 26.99(27) \\ 1851-60 & 46.46(29) & 3.07(41) & 5.83(41) & 63.22(6) & 5.20(11) & 64.44(29) & 11.49(11) & 17.24(41) \\ 1861-70 & 48.35(25) & 2.81(42) & 5.84(42) & 68.34(5) & 3.60(7) & 67.24(23) & 19.03(7) & 16.03(42) \\ 1871-80 & 50.02(17) & 3.30(27) & 3.66(27) & 52.60(6) & 2.59(5) & 62.99(13) & 14.08(8) & 12.41(25) \\ 1881-90 & 46.55(10) & 2.13(16) & 2.43(16) & 51.46(2) & 0.18(1) & 55.66(5) & 5.98(4) & 4.32(13) \\ 1891-1900 & 45.47(47) & 4.19(37) & 4.13(37) & 63.99(9) & 4.88(9) & 61.58(37) & 9.50(9) & 17.25(37) \\ 1901-10 & 43.48(100) & 4.02(89) & 5.91(89) & 60.67(18) & 5.80(15) & 64.94(85) & 14.75(18) & 21.47(86) \\ 1911-1917 & 41.89(61) & 3.98(43) & 5.73(43) & 59.91(7) & 5.20(6) & 61.83(42) & 16.19(7) & 19.52(42)\end{array}$




\section{ENDNOTES}

For comments and technical help I am grateful to Carolina and Pablo Bereciartua, Robert Crummey, Boris Mironov, Nicholas Riasanovsky, and Reginald Zelnik. My greatest debt is to Gregory Freeze, who supervised an early version of this paper as a B.A. honors thesis.

1. If during the First Empire in nineteenth-century France 47 percent of the episcopate were of noble origin, during the Third Republic only 4.5 percent were of noble background (see Jacques-Olivier Boudon, L'épiscopat français à l'époque concordataire [1802-1905]: Origines, formation, nomination [Paris, 1996], 56-58).

2. William Gibson, "The social origins and education of an élite: The nineteenthcentury episcopate," History of Education 20, no. 2 (1991): 97.

3. For the purpose of simplicity I will use "estate" instead of soslovie. For the connotations of soslovie that "estate" cannot capture see Gregory L. Freeze, "The Soslovie (Estate) Paradigm and Russian Social History," American Historical Review 91, no. 1 (February 1986): 11-36.

4. Gregory L. Freeze, ed. and trans., I. S. Belliustin, Description of the Clergy in Rural Russia. The Memoir of a Nineteenth-Century Parish Priest (Ithaca, 1985), 159. On the parish clergy further see Freeze, The Russian Levites. Parish Clergy in the Eighteenth Century (Cambridge, Mass., 1977); ibid., The Parish Clergy in Nineteenth-Century Russia. Crisis, Reform, Counter-Reform (Princeton, 1983).

5. For a still useful introduction to prosopography, also known as collective biography or multiple career-line analysis, see Lawrence Stone, "Prosopography," in The Past and the Present (Boston, 1981), 45-73. The first bishop in this study was consecrated on 3 March 1721, the last on 16 October 1917. For the bishops ordained between 1721 and 1893 a "list" or "register," compiled by the Holy Synod and published in 1896, served as the main source (Spiski arkhiereev ierarkhii userossiiskoi $i$ arkhiereiskikh kafedr so vremeni uchrezhdeniia Su. Prav. Sinoda [St. Petersburg, 1896]). This list contains raw biographical data with a bishop's lay name (during tonsure Russian monks were assigned monastic names), his birthday, his father's occupation, his education (including dates of graduation from ecclesiastical seminaries as well as the degrees he earned), the date and monastery of his tonsure, and the positions-typically in ecclesiastical education, monastic administration, or else as a parish priest-he held before his ordination as a bishop. Moreover, there are entries for the date of consecration, the dioceses the bishops were appointed to, the titles they held, the committees they belonged to, and the dates of their retirement and death. Especially in the eighteenth century these data are often incomplete. To fill in gaps I have consulted a Russian biographical dictionary (Russkii biograficheskii slovar', 25 vols. [Moscow-Petrograd, 1896-1916, reprinted in New York, 1962]). For the period of 1894 to 1917 the source was a compilation of short biographies, usually about two pages in length and more detailed than the lists of the Holy Synod. See Manuil Lemeshevskii, Russkie pravoslavnye ierarkhi, perioda s 1893 po 1965 gody (vkliuchitel'no), 6 vols. (Kuibyshev, 1966); reissued in the Russian original and annotated in German by P. Coelestin Patock, Die russischen orthodoxen Bischöfe, Bio-Bibliographie von Metropolit Manuil (Lemešeuskij), 6 vols. (Erlangen, 1979-1989). For the best short overview of the episcopate see Gregory L. Freeze, "Handmaiden of the State? The Church in Imperial Russia Reconsidered," Journal of Ecclesiastical History 36, no. 1 (January 1985): 95-98. Also see chap. 3 in Igor Smolitsch, Geschichte der russischen Kirche, 1700-1917, vol. 1 (Leiden, 1964), 357-427; Erich Bryner, Der Geistliche Stand in Rußland. Sozialgeschichtliche Untersuchungen zu Episkopat und Gemeindegeistlichkeit der russischen orthodoxen Kirche im 18. Jahrhundert (Göttingen, 1982), esp. 24-89. For an overview of the episcopate between 1893 and 1965, based on Lemeshevskii, see Coelestin Patock, "Die russischen orthodoxen Bischöfe der letzten 100 Jahre," in K. C. Felmy et al., ed., Tausend Jahre Christentum in Rußland. Zum Millenium der Taufe der Kiever Rus' (Göttingen, 1988), 435-444. 
6. For examples of Russian élite studies with at least a prosopographical component see Daniel Brower, Training the Nihilists. Education and Radicalism in Tsarist Russia (Ithaca, 1975); Robert Crummey, Aristocrats and Servitors. The Boyar Elite in Russia, 1613-1689 (Princeton, 1983); Dominic Lieven, Russia's Rulers under the Old Regime (New Haven, 1989); Roberta Thompson Manning, The Crisis of the Old Order in Russia. Gentry and Government (Princeton, 1982); Brenda Meehan-Waters, Autocracy and Aristocracy. The Russian Service Elite of 1730 (New Brunswick, 1982); Walter Pintner and Don Rowney, eds., Russian Officialdom. The Bureaucratization of Russian Society from the Seventeenth to the Twentieth Century (Chapel Hill, 1982).

7. See Igor Smolitsch, Russisches Mönchtum, Entstehung, Entwicklung und Wesen, 9881917 (Würzburg, 1953, reprinted in Amsterdam, 1978), 281. Smolitsch points out that continuous bonds were formed between certain dioceses and-usually nearby-monasteries, as abbots from one particular monastery were appointed prelates of a particular diocese generation after generation.

8. These three phases are based on a table of geographical origins by decade, which is not included in the appendix.

9. The two most influential figures in shaping Church policy during the early eighteenth century were both educated in the West. Patriarch in loco tenens, Stefan Iavorskii, studied philosophy at the Jesuit colleges of Lemberg and Lublin, theology in Vilna and Posen. Feofan Pokropovich received a Catholic scholastic education in a missionary college in Rome. For biographical vignettes on lavorskii and Pokropovich see Smolitsch, Geschichte der russischen Kirche, 76-99.

10. The Emperor was disappointed with the unexpected lack of support for his reforms from the non-Great Russian prelates, many of whom owed their positions to his personal intervention. See Bryner, 34-35.

11. On popular images of Peter see Nicholas Riasanovsky, The Image of Peter the Great in Russian History and Thought (New York, 1985), 74-85.

12. Twenty-one of these were Ukrainian, two Belorussian, and four foreign (from Serbia, Greece, and Rumanian duchies). Only sixteen were Great Russian. One bishop's heritage is ambiguous. See ibid., 29.

13. Among the dioceses occupied by non-Great Russians were Novgorod, Tver', Tobol'sk, Smolensk, and Pskov. See ibid., 30-31. Moreover, the patriarch in loco tenens, Stefan Iavorskii, was also Ukrainian. See Smolitsch, Geschichte der Russischen Kirche, 77.

14. For a summary of the causes explaining the change from non-Great Russian to Great Russian bishops see Bryner, 36-38. Bryner speculates that it was politically wise of Catherine, who was of German Protestant origin, to prefer Great Russians over Ukrainians and foreigners. Smolitsch paints a more complex picture of Catherine: her enlightenment superseded both her German Protestant and Russian Orthodox religiosity; in public life, however, she manipulated the popular appeal of Orthodox ritual. Moreover, Catherine was all too conscious of the danger inherent in Germanophilia, as Anne's (and Biron's) reign still loomed large as a loathsome example in Russia's popular imagination. See Smolitsch, Russisches Mönchtum, 397, 407.

15. The data on the pre-Petrine prelates have never been systematically investigated. They have only been treated on the basis of hagiobiographical sources that illustrate the heterogeneous social composition of the pre-Petrine episcopate. According to this analysis, bishops of noble origin seem to have predominated in terms of quantity; this conclusion, however, is dubious, for it is based on hagiographies that document the atypical lives of the noble bishops, who-prompted by "divine calling"-took monastic vows late in life. See Bryner, 54-56. 
16. The total of bishops consecrated in the 1700-25 period was forty-four (with data available for twenty-six). Percentages were computed from data in ibid., 56-59.

17. We know the social origins of thirty of the ninety-one bishops who were consecrated in the post-Petrine period.

18. The short biographical sources, from which the database for this study was assembled, often mentioned a bishop's paternal social status or occupation. The category "social origin" is based on this information.

19. The decline under Nicholas II was due to the temporary shortage of academy students who took their monastic vows. Hence in the 1870s through 1890s widowed parish priests were consecrated. Moreover, the seminaries, especially in the periphery of the Empire, took in students from other social estates.

20. For the clergy's social and functional structure see Freeze, The Parish Clergy in Nineteenth-Century Russia, 52-53.

\section{See Bryner, 65.}

22. On the clergy's place in the eighteenth century Russian social structure see chapter seven ("A Separate Society and Culture") in Freeze, The Russian Levites; for the nineteenth century see chapter four ("Service and Soslovie") in Freeze, The Parish Clergy in Nineteenth-Century Russia.

23. For 1721-1810 data are limited to forty-three bishops ( 23.5 percent), a reflection of the little-known pre-episcopal careers of Ukrainian prelates. Of the forty-three, almost half (48.8 percent) attended a seminary in the Empire's central region, 34.9 percent in the Northwest. For details see Appendix 3.

24. Since all four ecclesiastical academies had urban locations, the reality of the academy experience provided students, many of whom rented rooms in town, with direct social contact with townspeople; it can be argued, in fact, that academy students had stronger social ties with townspeople than with any other social group, including the clerical estate.

25. Interestingly, the Ecclesiastical Regulation of 1721 reflected Peter's demand for a practically educated society and deviated from the Kievan model by suggesting a full-year course in arithmetic and geometry. In their quest for a Latin curriculum the bishops of Ukrainian origin were thus able to assert themselves both against their Great Russian episcopal adversaries and the bureaucracy. See Freeze, The Russian Levites, 91.

26. On Latin in seminary and academy education see Maria Köhler-Baur, Die Geistlichen Akademien in Rußland im 19. Jahrhundert (Wiesbaden, 1997), 115-123.

27. See Freeze, The Parish Clergy in Nineteenth-Century Russia, 124-125.

28. Quoted in ibid., 136.

29. Ibid., 136-137.

30. For graphic accounts of violence exerted by teachers see ibid., 137-139. The power structure in the student body is treated in Freeze, The Russian Levites, 98-99.

31. Quoted in Freeze, The Parish Clergy in Nineteenth-Century Russia, 133.

32. Analyzed by reign, the following picture emerges: in the post-Petrine era bishops became 63.13 years old, under Catherine 64.86 years, and under Paul 59.98 years. During 
Alexander I's reign the hierarchy's average life expectancy was 66.36 years, under Nicholas I 72.27 years, in Alexander II's era 64.82 years, under Alexander III 53.36 years, and under the last Romanov, Nicholas II, 63.52 years.

33. On ecclesiastical academies now see Köhler-Baur, op. cit.

34. See Smolitsch, Russisches Mönchtum, 450.

35. Ibid., 450-451.

36. Rectors headed seminaries and academies. Inspectors were the second-ranking administrators who bore primary responsibility for student conduct and moral education.

37. Quoted in Freeze, The Parish Clergy in Nineteenth-Century Russia, 141.

38. On the comfortable economic position of the future prelates see Smolitsch, Russisches Mönchtum, 450. This picture, however, must be put into perspective: for example, in comparison with faculty at secular universities an academy professor earned seventy-four percent of the secular professor's salary; a seminary teacher received fifty-eight percent of a secular gymnasium teacher's pay. See Freeze, The Parish Clergy in Nineteenth-Century Russia, 115.

39. On the episcopal selection process see Bryner, 81-82. For the average age of bishops at the moment of consecration and all other statistics related to episcopal careers see Appendices 6.1. and 6.2.

40. Ibid., 83-84.

41. For a scathing examination of clergy-episcopal relations see Belliustin, 167-173.

42. For examples of politically motivated transfers see Bryner, 86-88.

43. Frequently transfer to another diocese was indeed linked with an advancement on the episcopal career ladder (in ascending order, the hierarchy was composed of suffragan bishops, bishops, archbishops, and mitropolitans, the latter post being reserved for Kiev, Moscow, and St. Petersburg).

44. See Freeze, The Parish Clergy in Nineteenth-Century Russia, 25-26.

45. For the canonical references to episcopal transfer see Bryner, 83-84. Closely related to the symbolism of a marriage between bishop and diocese was the imagery of a fatherchild relationship between prelate and cleric, invoked, for example, by Belliustin, 167 .

46. The transfer of power from "learned monks" to the clergy was propagated, inter alia, by Belliustin, 40. Also see Smolitsch, Russisches Mönchtum, 449.

47. Both quotes are in Freeze's introductory essay to Belliustin, 33.

48. See Gibson, op. cit.: 104-105.

49. Unlike the episcopate in Catholic continental Europe, the Henrician episcopate was comprised of nobles without royal ties and at least thirty percent from "socially minded nonnoble classes." See Andrew A. Chibi, "The Social and Regional Origins of the Henrician Episcopacy," Sixteenth Century Journal 29, no. 4 (1998): 964.

50. For the noble background of the Early Modern French episcopate see Joseph Bergin, The Making of the French Episcopate, 1589-1661 (New Haven, 1996), 187. During the 
period of 1589-1661, Bergin found that 63.24 percent of the bishops were from the nobility.

51. Jacques-Olivier Boudon, op. cit., 39-62.

52. See Alfred Minke, "Der 'belgische' Episkopat nach 1648-ein Vergleich," Römische Quartalschrift für christliche Altertumskunde und Kirchengeschichte 83, no. 1-4 (1988): 374.

53. See Johann Rainer, "Die Politik der Bischofsernennung in Österreich 1648-1803," Römische Quartalschrift für christliche Altertumskunde und Kirchengeschichte 85, no. 3-4 (1990): 233.

54. See Stephan Kremer, Herkunft und Werdegang geistlicher Führungsschichten in den Reichsbistümern zwischen Westfälischem Frieden und Säkularisation. Fürstbischöfe, Weihbischöfe, Generalvikare (Freiburg i. Br., 1992), 114.

55. Bergin, op. cit., 554-555.

56. See William T. Gibson, "The Professionalization of an Elite: The Nineteenth Century Episcopate," Albion 23, no. 3 (1991): 461. Gibson does not specify the average length of a bishop's tenure in one diocese. 